\title{
Brefeldin A blocks an early stage of protein transport in Candida albicans
}

\author{
Manabu Arioka, ${ }^{1} \uparrow$ Aiko Hirata, ${ }^{2}$ Akira Takatsuki ${ }^{1}$ and Makari Yamasaki ${ }^{1 *}$ \\ ${ }^{1}$ Department of Agricultural Chemistry and ${ }^{2}$ Institute of Applied Microbiology, The University of Tokyo, Bunkyo-ku, \\ Tokyo 113, Japan
}

(Received 31 October 1990; revised 12 February 1991; accepted 19 February 1991)

\begin{abstract}
Brefeldin A (BFA) inhibited in a dose-dependent manner secretion of the cell-surface enzyme acid phosphatase (APase) into the periplasm of Candida albicans and caused intracellular accumulation of enzyme protein. Cells grown in the presence of BFA became more dense, implying that cell-surface growth was also blocked by BFA treatment. The APase that was accumulated intracellularly migrated faster on SDS-PAGE, suggesting less $N$ linked glycosylation compared with the mature, periplasmic APase produced in the absence of BFA. Pulse-chase experiments and gel-filtration of oligosaccharides released by Endo $H$ treatment suggested that the coreglycosylated precursor form of APase accumulated in the presence of BFA. These results strongly suggested that endoplasmic reticulum (ER)-to-Golgi transport in $C$. albicans was inhibited by BFA. Aberrant membrane structures were observed in BFA-treated cells. Within $1 \mathrm{~h}$ of BFA removal these structures were replaced with rough ER membranes, suggesting that the accumulated membranes were derived from the ER.
\end{abstract}

\section{Introduction}

After synthesis on, and translocation across, the membranes of the rough endoplasmic reticulum (ER), secretory and membrane proteins are transported through the secretory pathway to their final destinations (Blobel \& Dobberstein, 1975; Palade, 1975). The detailed mechanism of the vectorial transport of proteins along the distinct secretory organelles is obscure, but it is generally thought that interorganelle movement of proteins proceeds by budding of vesicles that carry proteins between cell compartments.

Movement of proteins from the ER to the Golgi apparatus is the first step in vesicular transport between separate membrane-bound organelles (Pfeffer \& Rothman, 1987). It is also often the rate-limiting step in the secretion of proteins (Lodish et al., 1983; Warren, 1987). In addition, initial protein sorting has to be carried out in order to selectively retain resident ER proteins (Munro \& Pelham, 1987; Pelham, 1988; Tartakoff \& Vassalli, 1978). Clarifying the underlying mechanism of this process is one of the central issues in the study of protein secretion.

To date, several methods have been developed to study ER-to-Golgi transport processes in vivo and in vitro. First,

† Present address: Mitsubishi Kasei Institute of Life Sciences, 11 Minamiooya, Machida, Tokyo 197, Japan.

Abbreviations: APase, acid phosphatase; BFA, Brefeldin A; Endo H, endoglycosidase $H$; ER, endoplasmic reticulum. biochemical and histochemical techniques which combined autoradiography and cell fractionation revealed the general pathway of protein secretion, starting from the rough ER (Palade, 1975). It was also demonstrated that ER-to-Golgi transport could be inhibited by an inhibitor of oxidative phosphorylation (Jamieson \& Palade, 1968). Secondly, a genetic approach using temperature-sensitive secretory (sec) mutants of Saccharomyces cerevisiae demonstrated the involvement of more than 10 gene products in ER-to-Golgi transport process (Novick \& Schekman, 1979; Schekman, 1985). Thirdly, in vitro systems that reconstituted ER-to-Golgi protein transport were developed by employing semi-permeabilized mammalian and yeast cells (Baker et al., 1988; Beckers et al., 1987; Haselbeck \& Schekman, 1986; Ruohola et al., 1988; Simons \& Virta, 1987). These experiments have shown the existence of some factor(s) involved in ER-to-Golgi protein transfer as well as in other transport processes.

The use of specific inhibitors is another powerful means for analysing the mechanism of protein export (Griffiths et al., 1983; Tartakoff \& Vassalli, 1977, 1978). It can help to dissect the individual steps of the secretory pathway and therefore may be expected to reveal hitherto unknown aspects of intracellular protein transport. For example, morphological and biochemical analyses of the effect of the ionophore monensin have demonstrated that the acidic $\mathrm{pH}$ on the trans-side of the Golgi apparatus is necessary for protein transport from medial- to trans-Golgi (Griffiths et al., 1983). 
Brefeldin A (BFA) is a macrolide antibiotic produced by some fungi (see references in Hayashi et al., 1974). We have previously shown that BFA specifically inhibits intracellular transport of vesicular stomatitis virus (VSV) $\mathrm{G}$ protein in mammalian cells (Takatsuki \& Tamura, 1985). From biochemical analyses it was concluded that BFA interfered with transport before, or at, the cis-most cisterna of the Golgi apparatus. The aim of this study was to determine if BFA exerts the same effect in yeasts as it does in mammalian cells. For this purpose the effect of BFA on the secretion of a periplasmic enzyme, acid phosphatase (APase) in Candida albicans was examined.

\section{Methods}

Organism and materials. Candida albicans IAM 4888 was used throughout this study. YEPD medium contained $1 \%(w / v)$ Yeast Extract (Difco), $2 \%(w / v)$ peptone (Difco) and $2 \%(w / v)$ glucose. For induction of APase, $\mathrm{KH}_{2} \mathrm{PO}_{4}$ was replaced by equimolar $(11 \mathrm{mM}) \mathrm{KCl}$ in Burkholder medium (Burkholder, 1943). Glucose was replaced by galactose for efficient incorporation of $\left[{ }^{3} \mathrm{H}\right]$ mannose.

BFA was purified from cultures of a fungus isolated from soil samples as reported previously (Tamura et al., 1968). Zymolyase 100T and endoglycosidase $\mathrm{H}$ (Endo $\mathrm{H}$ ) were obtained from Seikagaku Kogyo Co. IgG sorb was from The Enzyme Center, Sephadex G-100 was from Pharmacia, and PMSF, leupeptin and pepstatin A were from Sigma. [ ${ }^{35}$ S]Methionine $\left[1113 \mathrm{Ci} \mathrm{mmol}{ }^{-1}\left(41 \mathrm{TBq} \mathrm{mmol}^{-1}\right)\right]$ was from Muromachi Kagaku Co. [ $\left.{ }^{3} \mathrm{H}\right]$ Mannose $\left[40.6 \mathrm{Ci} \mathrm{mmol}^{-1}\right.$ (1.5 TBq $\mathrm{mmol}^{-1}$ ) was from Daiichi Kagaku Co. All other reagents used were of analytical grade.

APase induction and the measurement of enzyme activity. APase was induced as described by Mizunaga (1979). Briefly, C. albicans IAM 4888 grown overnight at $30^{\circ} \mathrm{C}$ to exponential phase in YEPD medium $\left(\mathrm{OD}_{550}=2\right)$ was harvested by centrifugation $(700 \mathrm{~g}, 5 \mathrm{~min})$, washed twice with distilled water and suspended in Burkholder medium without inorganic phosphate $\left(\mathrm{OD}_{550}=1\right)$. BFA (methanolic solution) was added to give the indicated concentrations at the start of induction and was present throughout the following procedures. After incubation with shaking ( 150 r.p.m.) at $30^{\circ} \mathrm{C}$ for the times indicated cells were harvested, washed twice and suspended in protoplast buffer $(10 \mathrm{mM}$ Tris/ $\mathrm{HCl}, \mathrm{pH} 7.5,1.4 \mathrm{M}$-sorbitol, $5 \mathrm{~mm}-\mathrm{MgCl}_{2}$ and $10 \mathrm{~mm}-\mathrm{NaN}_{3}$ ). Zymolyase 100T $\left(100 \mu \mathrm{g} \mathrm{m}^{-1}\right)$ and 2-mercaptoethanol $(20 \mathrm{mM})$ were added and the suspension was incubated for 45-60 min. Protoplasts formed during this period were separated from the periplasm by centrifugation $(1500 \mathrm{~g}, 5 \mathrm{~min})$, washed twice with the protoplast buffer and disrupted by sonication (Branson Cell Disruptor 200) for $20 \mathrm{~s}$ on ice. The insoluble material was removed by centrifugation at $8000 \mathrm{~g}$ for $5 \mathrm{~min}$. The supernatant (protoplast lysate) and the periplasm fractions were assayed for APase activity as described by Mizunaga (1979). Values are expressed as units of APase activity per $\mathrm{OD}_{550}$ of cells.

Percoll density gradient. Cells treated with the designated concentrations of BFA for $3 \mathrm{~h}$ in YEPD medium were harvested, suspended in $2 \mathrm{ml}$ of ice-cold distilled water and loaded onto the top of $10 \mathrm{ml} 90 \%$ (v/v) Percoll in a Hitachi 13 PA tube. After centrifugation in a Hitachi RPS 40T rotor at 35000 r.p.m. for $30 \mathrm{~min}$, fractions were taken from the bottom of the tube by using a peristaltic pump. Samples from each fraction were appropriately diluted and spread on YEPD agar plates. The viable cell number of each fraction was determined and expressed as a percentage of the total number of cells detected either for the control or for each of the BFA concentrations.

Anti-APase antiserum. APase was purified from a C. albicans cell culture as described by Odds \& Hierholzer (1973) and used as immunogen to raise anti-APase antiserum in rabbits. The serum obtained had a titre of $>1: 2000$ in an ELISA reaction and could immunoprecipitate APase activity.

Radiolabelling and immunoprecipitation. After induction of APase for $2 \mathrm{~h}$ in phosphate-depleted medium as described above, cultures were incubated with or without BFA $\left(10 \mu \mathrm{g} \mathrm{m}^{-1}\right)$ for a further $15 \mathrm{~min}$. $\left[{ }^{35}\right.$ S]Methionine $\left[5 \mu \mathrm{Ci} \mathrm{ml}^{-1}\left(185 \mathrm{kBq} \mathrm{ml}^{-1}\right)\right]$ was then added and the cells were incubated for a further $3 \mathrm{~h}$. Labelled cells were harvested, washed, treated with Zymolyase and separated into periplasm and protoplast fractions as described. Protoplasts were lysed and centrifuged at $100000 \mathrm{~g}$ for $1 \mathrm{~h}$ to remove insoluble materials. Periplasm and protoplast fractions were incubated with anti-APase polyclonal antiserum for $14 \mathrm{~h}$ at $0{ }^{\circ} \mathrm{C}$. IgG sorb $(10 \%, w / v$, suspension; half the volume of antiserum) was added to the immunoreaction mixture, incubated on ice for $30 \mathrm{~min}$ with gentle shaking and centrifuged at 12000 r.p.m. for 1 min. The supernatant was removed and the precipitate was washed five times with immunoprecipitation buffer (100 mM-potassium phosphate buffer, $\mathrm{pH} 7.4,150 \mathrm{~mm}-\mathrm{NaCl}, 1 \%$, w/v, sodium deoxycholate, $0.05 \%$ SDS, $0.5 \%$ Triton X-100 and $0.5 \mathrm{~mm}-$ PMSF). The final precipitates were boiled for $3 \mathrm{~min}$ in SDS sample buffer and analysed by SDS-PAGE $(10 \%, \mathrm{w} / \mathrm{v}$, acrylamide $)$. The dried gels were enhanced and bands were visualized by fluorography at $-80^{\circ} \mathrm{C}$.

In pulse-chase experiments, cells incubated in phosphate-depleted medium for $2 \mathrm{~h}$ were pretreated with or without BFA for $15 \mathrm{~min}$, labelled with $500 \mu \mathrm{Ci}(18.5 \mathrm{MBq})\left[{ }^{35} \mathrm{~S}\right]$ methionine $\mathrm{ml}^{-1}$ for $10 \mathrm{~min}$ and chased by adding unlabelled methionine to $30 \mathrm{~mm}$. At the times indicated samples of cells were removed and frozen immediately in a solid $\mathrm{CO}_{2}$ /ethanol bath. After freezing and thawing at least five times, cells were treated with Zymolyase, lysed and immunoprecipitated as described.

The recovery of APase secretion was monitored using cells pretreated with BFA, labelled with $\left.{ }^{35} \mathrm{~S}\right]$ methionine for $60 \mathrm{~min}$ in the presence of BFA as described above, and then washed and chased in BFA-free medium containing $30 \mathrm{~mm}$ unlabelled methionine. Samples were removed at the recovery times indicated and processed as described above.

Endo $H$ treatment and gel filtration. Immunoprecipitated APase was treated with Endo $\mathrm{H}$ as follows. The immunoprecipitates were boiled for $3 \mathrm{~min}$ in $20 \mu 1 \mathrm{l} \%$ (w/v) SDS. Samples were cooled, adjusted to $20 \mathrm{mU}^{2}$ Endo $\mathrm{H} \mathrm{ml}^{-1}, 1 \mathrm{~mm}-\mathrm{PMSF}, 20 \mu \mathrm{g} \mathrm{ml}^{-1}$ each of leupeptin and pepstatin $\mathrm{A}, 0.02 \%(\mathrm{w} / \mathrm{v}) \mathrm{NaN}_{3}$ and $0.1 \% \mathrm{SDS}$ in $0.5 \mathrm{M}$-sodium citrate buffer, $\mathrm{pH} 5 \cdot 5$, and incubated for $16 \mathrm{~h}$ at $37^{\circ} \mathrm{C}$.

For efficient incorporation of $\left[{ }^{3} \mathrm{H}\right]$ mannose into saccharide chains, the carbon source of Burkholder medium was changed from $2 \%$ glucose to $0.5 \%$ galactose. After APase had been induced in this medium for $2 \mathrm{~h}$, cells were labelled with $1 \mu \mathrm{Ci}(37 \mathrm{kBq})\left[{ }^{3} \mathrm{H}\right]$ mannose $\mathrm{ml}^{-1}$ for $3 \mathrm{~h}$ in the presence or absence of $10 \mu \mathrm{g} \mathrm{BFA} \mathrm{ml}{ }^{-1}$. Cells were lysed by Zymolyase and sonication treatment, immunoprecipitated and treated with Endo $\mathrm{H}$ as above. The Endo-H-digested samples were boiled for $5 \mathrm{~min}$, centrifuged $(12000 \mathrm{~g}, 10 \mathrm{~min})$ and the final supernatant was applied to a Sephadex G-100 column $(1 \cdot 1 \times 45 \mathrm{~cm})$, pre-equilibrated and eluted with $150 \mathrm{~mm}-\mathrm{NaCl}$. Fractions of $1 \mathrm{ml}$ were collected, dried on Whatman GF/C filters and the radioactivity was measured. Molecular mass calibration was done with blue dextran, bovine serum albumin $(69 \mathrm{kDa})$, ovalbumin $(45 \mathrm{kDa})$, lysozyme $(14.3 \mathrm{kDa})$ and $\left[{ }^{3} \mathrm{H}\right]$ mannose as standards.

Electron microscopy. Preparation of thin sections of yeast cells by freeze-substitution done as described by Tanaka \& Kanbe (1986) with 
minor modifications. Cells grown in the presence or absence of $10 \mu \mathrm{g}$ BFA ml-1 in Burkholder medium for $10 \mathrm{~h}$ were collected on copper meshes and plunged into liquid propane cooled with liquid $\mathrm{N}_{2}$. Frozen cells were transferred to $2 \%(\mathrm{w} / \mathrm{v}) \mathrm{OsO}_{4}$ in anhydrous acetone, and kept at $-80^{\circ} \mathrm{C}$ for $48 \mathrm{~h}$ with solid $\mathrm{CO}_{2} /$ acetone. They were transferred to $-35^{\circ} \mathrm{C}$ for $2 \mathrm{~h}, 4^{\circ} \mathrm{C}$ for $2 \mathrm{~h}$ and then to room temperature for $2 \mathrm{~h}$. After washing three times with absolute acetone, samples were infiltrated with increasing concentrations of Spurr's resin in absolute acetone and finally with $100 \%$ Spurr's resin. They were then polymerized in capsules at $50{ }^{\circ} \mathrm{C}$ for $5 \mathrm{~h}$ and $70^{\circ} \mathrm{C}$ for $30 \mathrm{~h}$. Thin sections cut with a Sorvall MT-2 ultramicrotome were collected, stained with uranyl acetate and lead citrate and observed in a JEOL $200 \mathrm{CX}$ electron microscope at $100 \mathrm{kV}$.

\section{Results}

\section{$B F A$ inhibits protein secretion in C. albicans}

Most of the studies of the mechanism of protein secretion in yeasts have used Saccharomyces cerevisiae (Schekman, 1985). This organism is relatively insensitive to BFA, making it an unsuitable organism for analysing the action of BFA. In contrast, previous work showed that Candida albicans IAM 4888 was the most sensitive of the yeasts tested to BFA (Hayashi et al., 1982). Thus we selected this strain of $C$. albicans to study the action of BFA on protein secretion in yeast.

The effect of BFA on the secretion of the $C$. albicans cell-surface glycoprotein APase was examined. As shown in Fig. $1(a)$, BFA inhibited secretion of APase in a dose-dependent manner. At the highest BFA concentration tested $\left(10 \mu \mathrm{g} \mathrm{ml}^{-1}\right)$, APase secretion was only one-tenth that of untreated control cells. In contrast, a several-fold increase in intracellular APase activity was observed in BFA-treated cells compared with that of the controls, indicating intracellular accumulation of the enzyme (Fig. 1b). BFA had little effect on the incorporation of labelled leucine into TCA-insoluble fractions (Hayashi et al., 1982, and our unpublished data), which suggests that decrease in periplasmic APase activity was due to the inhibition of APase secretion rather than the inhibition of protein synthesis. Several possibilities could be considered to account for the accumulation of less APase at 5 and $10 \mu \mathrm{g} \mathrm{BFA} \mathrm{ml} l^{-1}$ than at $2.5 \mu \mathrm{g} \mathrm{ml}^{-1}$. For example, BFA might cause selective inhibition of secretory protein synthesis, or accumulation of inactive forms of APase and degradation of APase accumulated within the cells.

Transport of plasma-membrane proteins to the cell surface is known to depend on the secretory pathway as is the discharge of proteins into the periplasm or culture medium (Brada \& Schekman, 1988). If intracellular protein transport is blocked by BFA, plasma-membrane proteins are unable to reach the cell surface and therefore accumulate within the cells, resulting in severe decrease

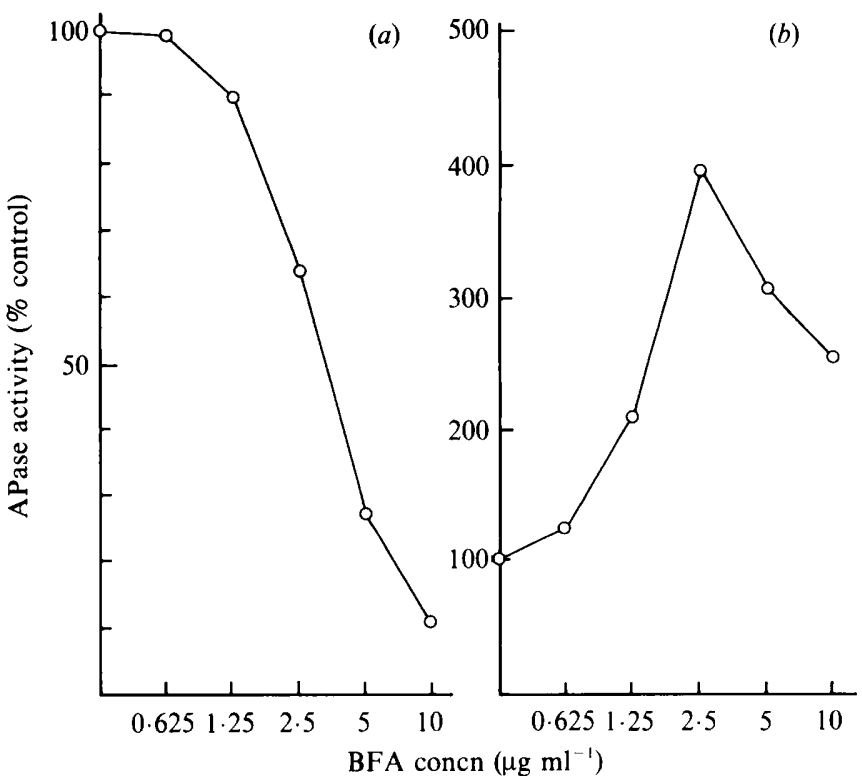

Fig. 1. Inhibition of APase secretion by BFA. C. albicans IAM 4888 was grown in phosphate-depleted medium in the presence of the indicated concentrations of BFA. After $5 \mathrm{~h}$ cells were harvested and converted to spheroplasts by treatment with Zymolyase; APase activities in both periplasm $(a)$ and protoplast lysate $(b)$ fractions were then determined. Values are expressed as percentages of the control; $100 \%$ activity $=9.6 \times 10^{-2} \mathrm{U}\left(\mathrm{OD}_{550}\right)^{-1}$. Points represent single determinations of APase activity. The experiment was repeated three times with essentially the same results.

or cessation of net cell-surface growth. Since synthesis of proteins, DNA and RNA is hardly affected by BFA treatment (Hayashi et al., 1982), continuous synthesis of macromolecules may be expected to increase the density of BFA-treated cells. To test this possibility, we looked for changes in cell density after BFA treatment. Cells incubated in the presence or absence of BFA for $3 \mathrm{~h}$ were loaded onto $90 \%$ Percoll, centrifuged and fractionated; the viable cell numbers in each fraction were then determined as described in Methods. As shown in Fig. 2, viable cell counts in the bottom fraction (fraction no. 1) increased after BFA treatment, indicating that cells grown in the presence of BFA became more dense than untreated control cells. The total number of viable cells was essentially the same at each BFA concentration. The proportion of dense cells was increased by raising the concentration of BFA, suggesting that inhibition of transport, incomplete at lower BFA concentrations, gradually became greater with increasing BFA concentration. This dose-dependency is in good accord with the effect shown above on secretion of APase. Taken together, these results suggest that BFA inhibits protein secretion in $C$. albicans and, consequently, causes intracellular accumulation of proteins normally destined for the cell surface, resulting in an increase in cell density. 


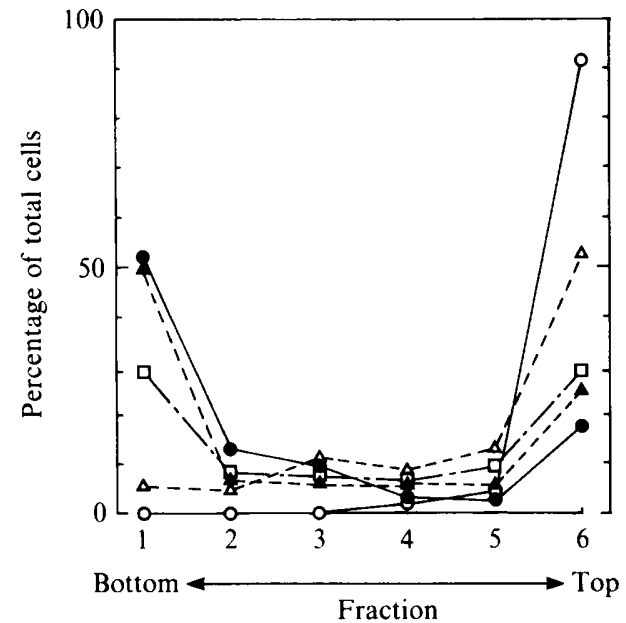

Fig. 2. Percoll density gradient centrifugation of BFA-treated and untreated cells. Cells incubated in the presence of the indicated concentrations of BFA for $3 \mathrm{~h}$ in YEPD medium were collected and loaded onto $90 \%$ Percoll. After centrifugation, fractions were collected from the bottom and spread on YEPD agar plates. The number of colonies was counted after $2 \mathrm{~d}$. BFA concentrations $\left(\mu \mathrm{g} \mathrm{ml}^{-1}\right): 0,0$; $\triangle, 2 ; \square, 4 ; \Delta, 6 ; 0,10$. Points represent single determinations of viable cell counts. The experiment was repeated twice with essentially the same results.

\section{The effect of $B F A$ is rapid and reversible}

In sec mutants of $S$. cerevisiae, secretion of cell-surface glycoproteins stops immediately upon incubation at the restrictive temperature (Novick et al., 1980, 1981). The transport block is reversible, accumulated glycoproteins being secreted to the periplasm on return to the permissive temperature. A similar rapid and reversible effect was observed with BFA. Upon addition of $10 \mu \mathrm{g}$ BFA $\mathrm{ml}^{-1}$, secretion of APase into the periplasm stopped immediately and simultaneously APase began to accumulate within the protoplasts (Fig. $3 a, b$ ). After BFA treatment for $2 \mathrm{~h}$, cells were collected, washed and resuspended in fresh, BFA-free medium. Secretion of APase quickly resumed after the removal of BFA and the amount of APase accumulated within the protoplasts began to fall with little lag period (Fig. $3 a, b$ ). Thus the inhibition of secretion caused by BFA was very rapid and almost completely reversible.

\section{An early stage of intracellular transport is blocked by $B F A$}

$N$-Linked oligosaccharide moieties of glycoproteins are assembled sequentially within distinct compartments of the secretory pathway (Ballou, 1976; Byrd et al., 1982; Esmon et al., 1981). Core-glycosylation and trimming of three glucose residues and one mannose residue take place in the ER while bulky outer-chain carbohydrates

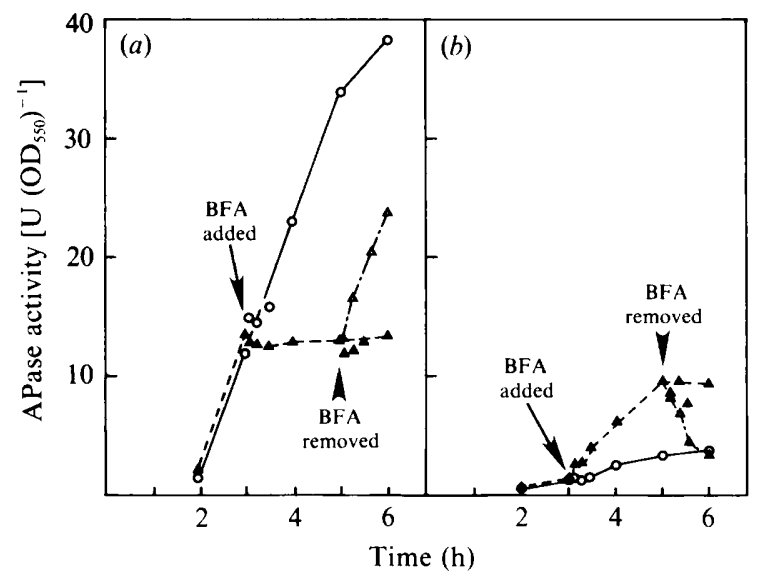

Fig. 3. Rapid and reversible effect of BFA. After induction of APase for $3 \mathrm{~h}$ cells were treated for $2 \mathrm{~h}$ with BFA $\left(10 \mu \mathrm{g} \mathrm{ml}^{-1}\right)(\boldsymbol{\Delta})$ or were left untreated $(O)$. Treated cells were separated into two equal portions: one half was further incubated in the presence of BFA ( $\mathbf{A})$, the other was quickly washed twice with distilled water and incubated in the absence of BFA $(\triangle)$. After $0,5,10,20$, and 60 min cells were collected, converted to protoplasts and APase activities in both periplasm $(a)$ and protoplast lysate $(b)$ fractions were determined. Points represent single determinations of APase activity. The experiment was repeated twice with essentially the same results.

are added to core oligosaccharides in the Golgi apparatus. Thus the extent of modification of $N$-linked carbohydrates can be used to determine the location of the protein of interest. To assess the site of inhibition of intracellular transport and eventual accumulation of APase caused by BFA treatment, we compared the degree of APase glycosylation in the presence or absence of BFA by immunoprecipitation followed by SDSPAGE.

In the periplasm fraction of the control, an intense smeared band of secreted, mature-form APase was present, migrating with an apparent molecular mass of 120-150 kDa (Fig. 4, lane 4; Odds \& Hierholzer, 1973). In contrast, in the BFA-treated cells APase could not be detected in the periplasm but only in the protoplast fraction, again indicating inhibition of secretion and intracellular accumulation of APase (Fig. 4, lanes 9 and 7 , respectively). In the latter case, the APase migrated with an apparent molecular mass of $96 \mathrm{kDa}$, which is considerably smaller than that of mature APase. This difference in molecular mass is presumably due to the extent of $N$-linked glycosylation, since Endo $\mathrm{H}$ treatment converted APase from both BFA-treated and untreated cells to proteins of $76 \mathrm{kDa}$ and $51 \mathrm{kDa}$ (Fig. 4, lanes 5 and 8 , respectively). The $51 \mathrm{kDa}$ band and the lower molecular mass band in lane 7 may be degradation products. Since heterogeneous electrophoretic mobility of mature APase is thought to be attributable to the addition of outer-chain carbohydrates in the Golgi 


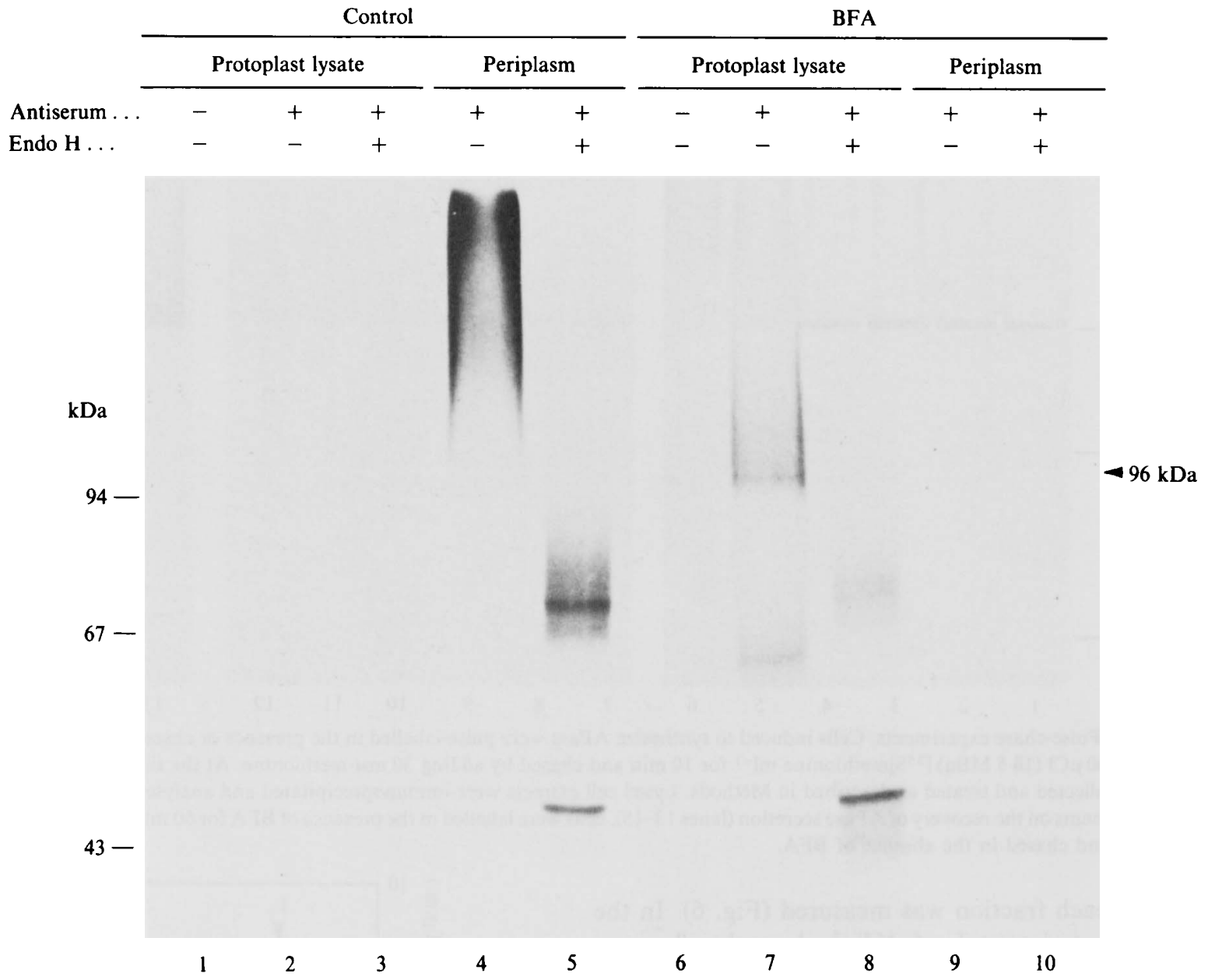

Fig. 4. Immunoprecipitation of APase in BFA-treated and untreated cells. Cells induced to synthesize APase for $2 \mathrm{~h}$ were labelled with $\left.5 \mu \mathrm{Ci}(185 \mathrm{kBq}){ }^{35} \mathrm{~S}\right]$ methionine $\mathrm{ml}^{-1}$ in the presence or absence of $10 \mu \mathrm{g} \mathrm{BFA} \mathrm{ml}{ }^{-1}$ for $3 \mathrm{~h}$. They were converted to protoplasts and APase in the periplasm and the protoplast lysate fractions was immunoprecipitated, treated with Endo $\mathrm{H}$ and analysed by SDS-PAGE.

apparatus, it would be expected that the $96 \mathrm{kDa}$ species of APase, which migrated relatively homogeneously and accumulated in the presence of BFA, does not contain outer-chain carbohydrates but is modified only by core oligosaccharides. An indirect examination of this possibility was made in a pulse-chase experiment (Fig. 5). The $96 \mathrm{kDa}$ species was the most abundant form of APase after a 10 min labelling period in both control and BFAtreated cells (Fig. 5, lanes 1 and 7). In the control the amount of this species of APase gradually decreased as it was converted during the chase to mature APase with lower and heterogeneous electrophoretic mobility, suggesting that the $96 \mathrm{kDa}$ species is an intermediate in the formation of the highly glycosylated mature APase (Fig. 5 , lanes 1-6). However, when the pulse-chase experiment was done in the presence of BFA, conversion of the $96 \mathrm{kDa}$ species to the mature form was not observed, the amount of the $96 \mathrm{kDa}$ species remaining relatively constant throughout the chase period (Fig. 5, lanes 7-12). When BFA-treated cells were washed and re-incubated in BFA-free medium, this $96 \mathrm{kDa}$ species appeared to be converted to highly glycosylated mature APase as observed in the control (Fig. 5, lanes 13-15). These results suggest that the $96 \mathrm{kDa}$ species that accumulated in the presence of BFA is the APase precursor which is detected immediately after pulse-labelling. The rapid radiolabelling of the $96 \mathrm{kDa}$ species with homogeneous electrophoretic mobility and its subsequent conversion to diffusely migrating mature APase, which seems to contain outer-chain carbohydrates, strongly suggest that the $96 \mathrm{kDa}$ species is the core-glycosylated precursor of APase.

To confirm that the $96 \mathrm{kDa}$ species is indeed the coreglycosylated form of APase, an estimation was made of the molecular masses of the $N$-linked carbohydrates liberated by Endo $\mathrm{H}$ treatment. APase was labelled with $\left[{ }^{3} \mathrm{H}\right]$ mannose in the presence or absence of BFA, immunoprecipitated and digested with Endo H. Released carbohydrate moieties were then passed through a Sephadex G-100 gel filtration column and the radio- 


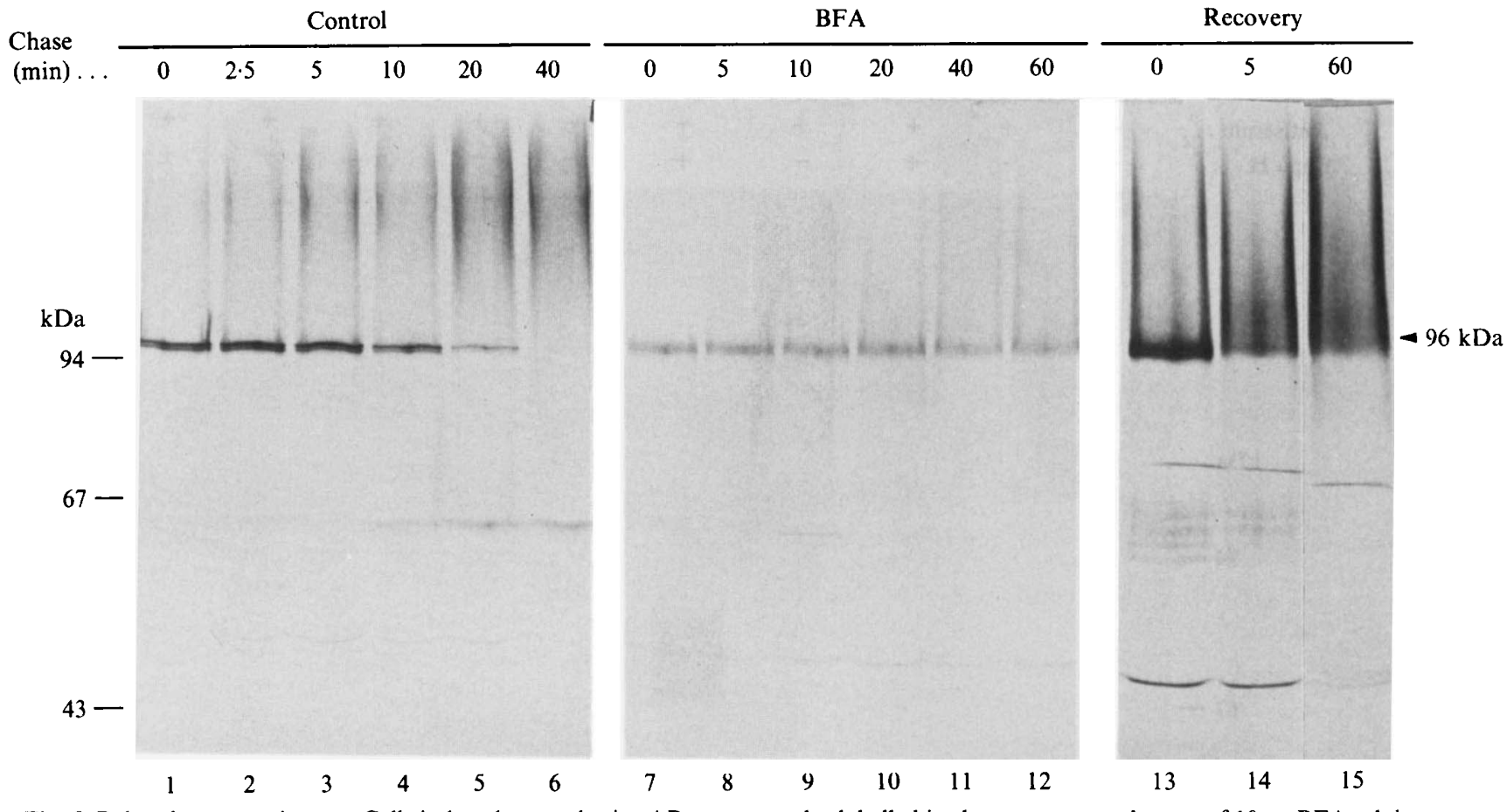

Fig. 5. Pulse-chase experiments. Cells induced to synthesize APase were pulse-labelled in the presence or absence of $10 \mu \mathrm{g} \mathrm{BFA} \mathrm{ml}{ }^{-1}$ with $\left.500 \mu \mathrm{Cl}(18.5 \mathrm{MBq}){ }^{35} \mathrm{~S}\right]$ methionine $\mathrm{ml}^{-1}$ for $10 \mathrm{~min}$ and chased by adding $30 \mathrm{mM}$-methionine. At the times indicated samples were collected and treated as described in Methods. Lysed cell extracts were immunoprecipitated and analysed by SDS-PAGE. For experiments on the recovery of APase secretion (lanes 13-15), cells were labelled in the presence of BFA for 60 min, and quickly washed twice and chased in the absence of BFA.

activity in each fraction was measured (Fig. 6). In the control, the major peak of $N$-linked saccharides was eluted near the void volume of the column, fraction no.18, and its molecular mass was determined to be 25 $40 \mathrm{kDa}$. In contrast, in BFA-treated cells the major peak appeared around fraction no. 44, which corresponds to a molecular mass of $2 \cdot 5-4 \mathrm{kDa}$ (Fig. 6), close to the molecular mass of the core oligosaccharide (about $2 \mathrm{kDa}$ ). Although structural analysis of the oligosaccharide in this peak fraction was not done, the results suggest that the $96 \mathrm{kDa}$ species of APase that accumulates in BFA-treated cells has acquired core oligosaccharides but not outer-chains. Note that as proteins were used as molecular mass standards, the molecular mass values that we quote for carbohydrates are approximate.

Since core oligosaccharides are added to exported proteins in the ER, the fact that the core-glycosylated $96 \mathrm{kDa}$ species of APase accumulated intracellularly as a result of BFA treatment again strongly suggests that APase was retained in the ER or in the compartments before the Golgi apparatus, where outer-chain carbohydrates are assembled. Thus we propose that in C.albicans

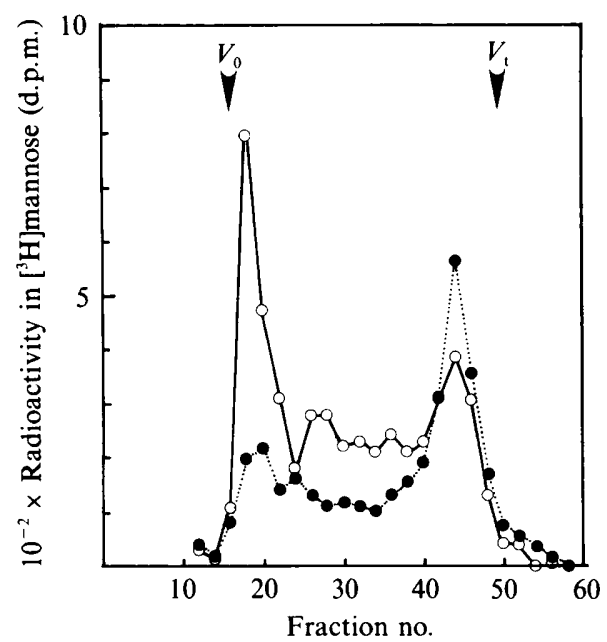

Fig. 6. Gel-filtration of $N$-linked saccharides of APase. APase induced in Burkholder medium containing $0.5 \%$ galactose was labelled with $1 \mu \mathrm{Ci}(37 \mathrm{kBq})\left[{ }^{3} \mathrm{H}\right]$ mannose $\mathrm{ml}^{-1}$ for $3 \mathrm{~h}$ in the absence $(\mathrm{O})$ or

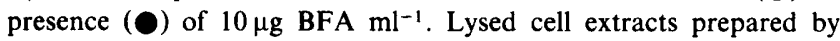
Zymolyase treatment were immunoprecipitated and digested with Endo H. Released $N$-linked saccharide chains were applied to a Sephadex G-100 column, fractionated, and the radioactivity in each fraction was determined. Similar results were obtained in two experiments with samples from independent cultures.

Fig. 7. Electron micrographs of BFA-treated and untreated cells. (a) Control C. albicans cells. (b) Marked proliferation of internal membrane structure in cells treated with BFA $\left(10 \mu \mathrm{g} \mathrm{ml}^{-1}\right)$ for $10 \mathrm{~h} .(c, d)$ Cells treated with BFA for $10 \mathrm{~h}$. Aberrant membranes are continuous with the outer nuclear membrane (in $c, \mathrm{~N}$ marks the nucleus). Stacks of membrane structures were formed on the luminal side of the proliferated membrane (in $d$, arrowheads). ( $e, f$ ) Concentric membrane structure observed in BFA-treated cells. Membranes were closely packed together and the central region of the structure was filled with ribosome-like particles. Bars: $1 \mu \mathrm{m}$ in $(a),(b)$ and $(e)$; $0.5 \mu \mathrm{m}$ in $(c),(d)$ and $(f)$. 

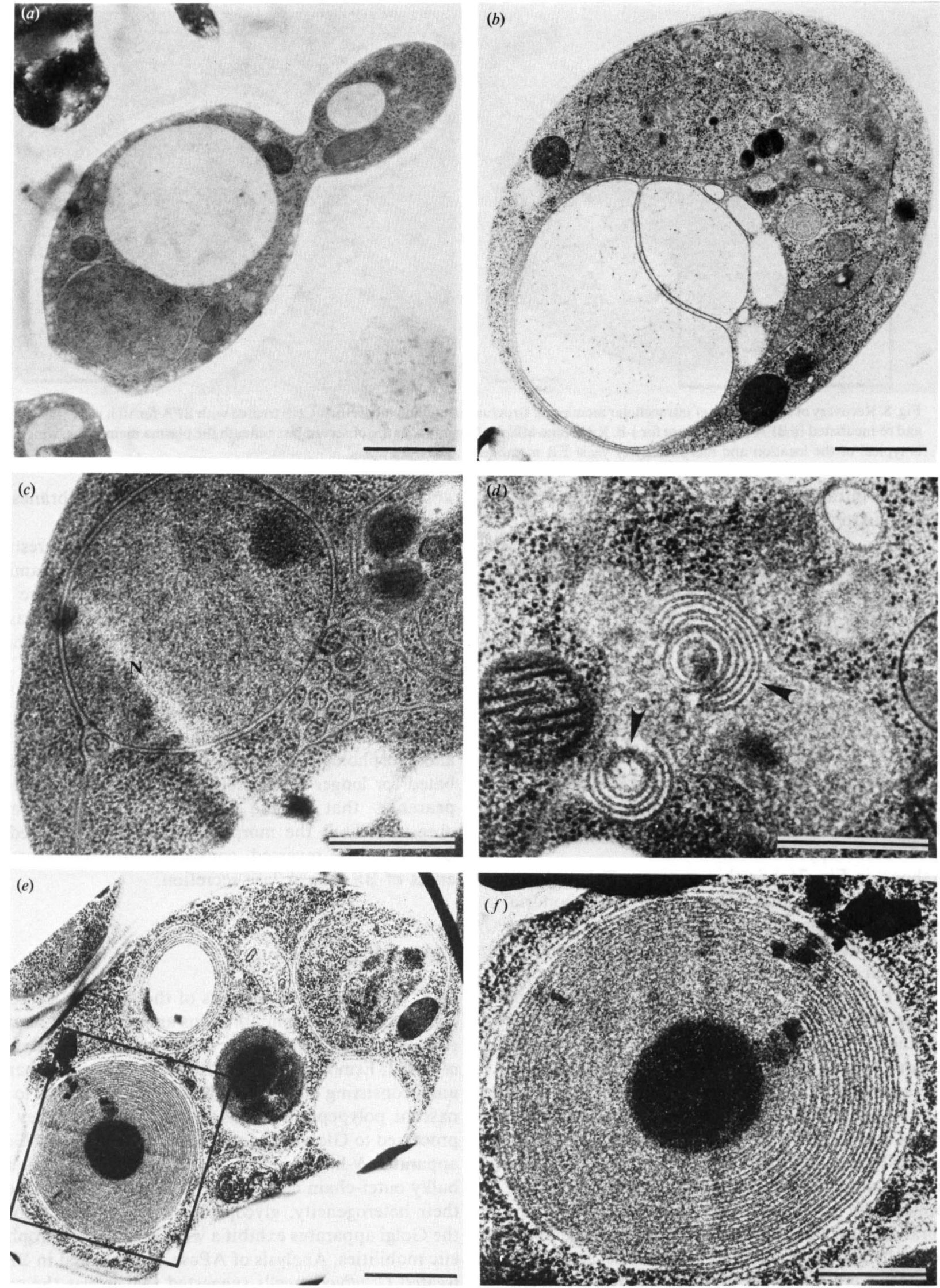

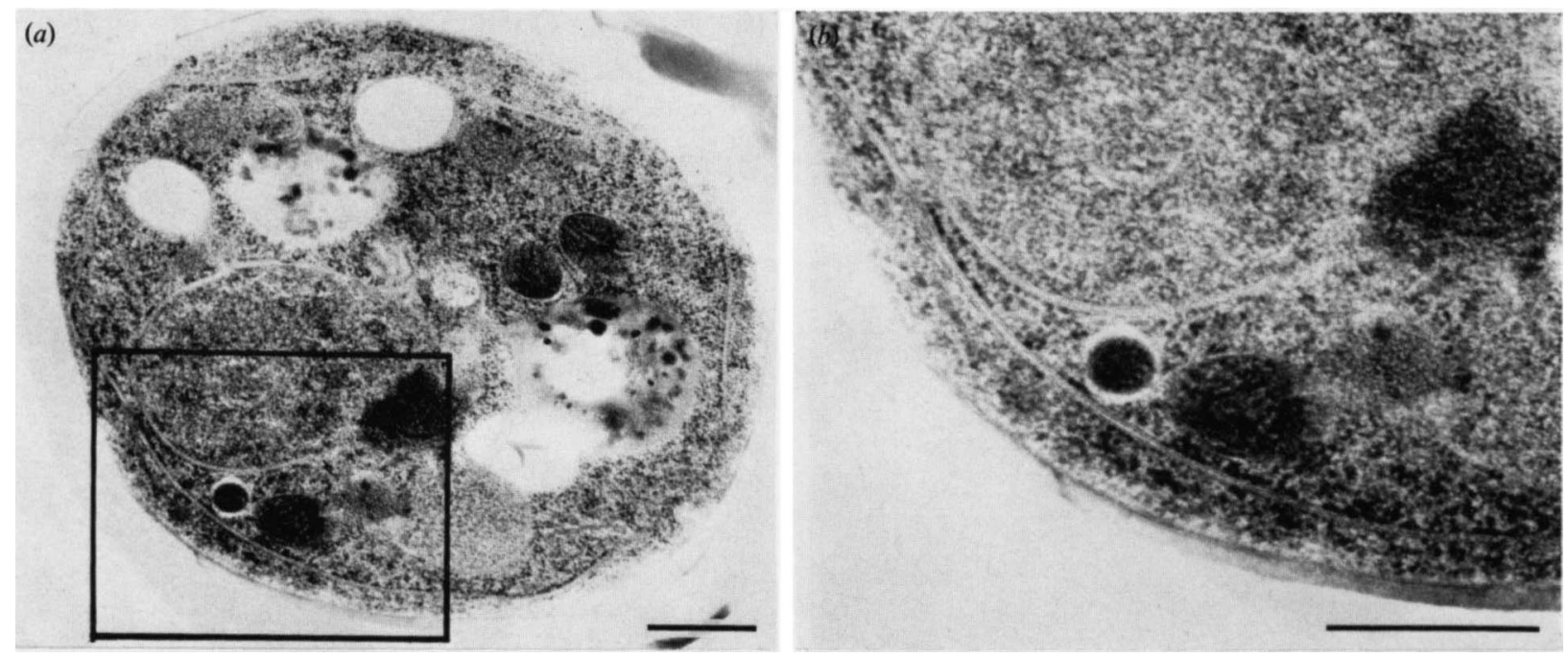

Fig. 8. Recovery of morphology of intracellular membrane structure after removal of BFA. Cells treated with BFA for $10 \mathrm{~h}$ were washed and re-incubated in BFA-free medium for $1 \mathrm{~h}$. Ribosome-attached membranes are observed just beneath the plasma membrane, which is typical of the location and morphology of yeast ER membranes. Bars, $0.5 \mu \mathrm{m}$.

BFA blocks intracellular protein transport between the ER and the Golgi apparatus, as in animal cells.

\section{BFA treatment induces aberrant intracellular membrane structures}

Observation by light microscopy demonstrated that the morphology of BFA-treated cells changed from the typical ovoid form to a spherical shape, which was always accompanied by changes in refractivity. BFA also caused the cell volume to increase to two to three times that of the control cells (Hayashi et al., 1982). In order to examine the morphological changes at the ultrastructural level, cells fixed and processed by freezesubstitution (Tanaka \& Kanbe, 1986) were observed by electron microscopy.

As shown in Fig. 7(a), in thin sections of control cells internal membranes other than nuclear, mitochondrial and vacuolar membranes were rarely seen. On the other hand, cells treated with BFA for $10 \mathrm{~h}$ showed dramatic accumulation of membrane structures of unknown origin (Fig. $7 b-f$ ). These structures were found throughout the cytoplasm and most of them were smooth, ribosome-free membranes. They were, at least in some places, continuous with the outer nuclear membrane (Fig. 7c), which suggests that they are derived from the ER. In some cells the luminal side of these membrane structures expanded and enclosed stacks of membranes (Fig. $7 d$ ). Occasionally, an unusual membrane structure was observed in which more than ten membrane units were assembled into a concentric circle (Fig. 7e,f). The membranes were very closely packed with little space between them and in the centre of these concentric membranes were a number of small particles, presum- ably ribosomes, suggesting that these membranes are surrounding cytoplasm.

The effect of BFA is reversible and secretion resumes readily after removal of BFA (Fig. 3). We next examined if the BFA-induced morphological changes were also reversible. Cells treated with BFA for $10 \mathrm{~h}$ were washed and re-incubated in BFA-free medium for $1 \mathrm{~h}$. As shown in Fig. $8(a, b)$, the irregularly shaped membranes that accumulated in the presence of BFA largely disappeared and ribosome-bound membranes were observed just beneath the cell membrane, which is the typical location and morphology of yeast ER membranes. Cells incubated for longer periods $(10 \mathrm{~h})$ showed the normal appearance, that is, the ER membranes were rarely observed. Thus the morphological changes caused by BFA could be reversed, consistent with the reversible effect of BFA on APase secretion.

\section{Discussion}

In $S$. cerevisiae, modifications of the $N$-linked carbohydrate moieties of mannoproteins are carried out sequentially in transit through the secretory pathway (Byrd $e t$ al., 1982; Esmon et al., 1981, 1984). Core oligosaccharide units consisting of $\mathrm{GlNAC}_{2} \mathrm{Man}_{9} \mathrm{Glc}_{3}$ are added to the nascent polypeptide chains in the ER where they are processed to GlcNAc $2 \mathrm{Man}_{8}$. After delivery to the Golgi apparatus $N$-linked sugars are elongated by addition of bulky outer-chain carbohydrates (Ballou, 1976). Due to their heterogeneity, glycoproteins transported through the Golgi apparatus exhibit a wide range of electrophoretic mobilities. Analysis of APase accumulated in BFAitreated $C$. albicans cells suggested that it was the core- 
glycosylated precursor form, which meant that it had not reached the Golgi apparatus. Thus it is probable that in C. albicans BFA inhibits protein transport between the ER and the Golgi apparatus, as in animal cells.

BFA-treated cells accumulated abnormal membrane structures (Fig. 7b-f). The origin and nature of these membranes are unknown, but they have some resemblance to the accumulated network of ER membranes seen in some ER-exaggerating sec mutants (Novick \& Schekman, 1979; Novick et al., 1980, 1981) and they are also reminiscent of structures observed in the coldsensitive ypt 1-1 mutant of $S$. cerevisiae (Schmitt et al., 1988). Considering that these mutants have defects in transport from the ER to the Golgi apparatus, together with the fact that BFA inhibits a similar step in intracellular protein transport in C. albicans and in animal cells, it can be speculated that the accumulated membrane structures of BFA-treated cells are an abnormally proliferated version of the ER. The observations that at least some portions of accumulated membranes are continuous with the outer-nuclear membrane and that significant amounts of ribosome-attached membranes, that are rarely seen in control cells, appeared during recovery from BFA treatment, support this. Furthermore, our unpublished observations that the membranes accumulated in BFA-treated cells are little or weakly stained by the periodic acid/thiocarbohydrazide/silver protein method, which specifically stains 'Berkely bodies' in $\sec 7$ mutants (Novick et al., 1980,1981 ), indicate that these membranes are not derived from the Golgi apparatus.

A small percentage of BFA-treated cells contained concentric membrane structures made up of more than 10 layers of packed membranes (Fig. 7e,f). It is unlikely that these are artifacts generated in the process of specimen preparation, since the freeze-substitution method used is thought to be the most suitable procedure for retaining the features of intact cells. Similar remarkable proliferation of stacked concentric membrane structures was observed in animal and yeast cells by Orci et al. (1984) and by Wright et al. (1988). In both these cases overproduction of HMG-CoA reductase, an integral membrane protein of the ER, resulted in marked accumulation of membrane structures called 'crystalloid ER' and 'karmellae', respectively. However, it is unlikely that the appearance of concentric membranes in BFAtreated cells is the direct consequence of overproduction of HMG-CoA reductase, since no increase in HMG$\mathrm{CoA}$ reductase activity was observed in BFA-treated cells (unpublished data).

Recent studies from two laboratories (Doms et al., 1989; Lippincott-Schwartz et al., 1989) focused on the Golgi apparatus as the target organelle of BFA action in mammalian cells. One possible explanation is that BFA causes the cis- and medial-Golgi cisternae to vesiculate, disappear and fuse inappropriately with the ER, so that eventually protein transport will cease due to the absence of the Golgi apparatus. If this is the case with C.albicans, then the Golgi membranes that fused with the ER membranes did not retain Golgi-like characteristics. The rare existence in control $C$. albicans cells of the typical Golgi structures seen in animal and plant cells prevented us from directly comparing morphological changes of the Golgi apparatus caused by BFA in yeast.

This work was supported by a Grant-in-Aid for Scientific Research from the Ministry of Education, Science and Culture of Japan.

\section{References}

Baker, B., Hicke, L., Rexach, M., Schleyer, M. \& Schekman, R. (1988). Reconstitution of SEC gene product-dependent intercompartmental protein transport. Cell 54, 335-344.

Ballou, C. E. (1976). Structure and biosynthesis of the mannan component of the yeast cell envelope. Advances in Microbiology and Physiology 14, 93-158.

Beckers, C. J. M., Keller, D. S. \& Balch, W. E. (1987). Semi-intact cells permeable to macromolecules: use in reconstitution of protein transport from the endoplasmic reticulum to the Golgi complex. Cell 50, 523-534.

Blobel, G., \& Dobberstein, B. (1975). Transfer of proteins across membranes. II. Reconstitution of functional rough microsomes from heterologous components. Journal of Cell Biology 67, 852 862.

BraDA, D. \& SCHEKMAN, R. (1988). Coincident localization of secretory and plasma membrane proteins in organelles of the yeast secretory pathway. Journal of Bacteriology 170, 2775-2783.

BURKHOlder, P. R. (1943). Vitamin deficiencies in yeasts. American Journal of Botany 30, 206-211.

Byrd, J. C., Tarentino, A. L., Maley, F., Atkinson, P. H. \& Trimble, R. B. (1982). Glycoprotein synthesis in yeast. Journal of Biological Chemistry 257, 14657-14666.

Doms, R. W., Russ, G. \& Yewdell, J. W. (1989). Brefeldin A redistributes resident and itinerant Golgi proteins to the endoplasmic reticulum. Journal of Cell Biology 109, 61-72.

Esmon, B., Novick, P. \& Schekman, R. (1981). Compartmentalized assembly of oligosaccharides on exported glycoproteins in yeast. Cell $25,451-460$.

ESMON, B., ESMON, P. \& SCHEKMAN, R. (1984). Early steps in processing of yeast glycoproteins. Journal of Biological Chemistry 259, 1032210327

GriffThs, G., QuinN, P. \& WarRen, G. (1983). Dissection of the Golgi complex. I. Monensin inhibits the transport of viral membrane proteins from medial to trans Golgi cisternae in baby hamster kidney cells infected with Semliki Forest virus. Journal of Cell Biology 96, 835-850.

HaselbeCK, A. \& Schekman, R. (1986). Interorganelle transfer and glycosylation of yeast invertase in vitro. Proceedings of the National Academy of Sciences of the United States of America 83, 2017-2021.

Hayashi, T., Takatsuki, A. \& Tamura, G. (1974). The action mechanism of Brefeldin A. I. Growth recovery of Candida albicans by lipids from the action of Brefeldin A. Journal of Antibiotics 27, 65 72 .

Hayashi, T., Takatsuki, A. \& Tamura, G. (1982). Effect of Brefeldin A on biosynthesis of cellular components in Candida albicans. Agricultural and Biological Chemistry 46, 2241-2248.

JAMIESON, J. D. \& PALADE, G. E. (1968). Intracellular transport of secretory proteins in the pancreatic exocrine cell. IV. Metabolic requirements. Journal of Cell Biology 39, 589-603. 
Lippincott-Schwartz, J., Yuan, L. C., Bonifacino, J. S. \& KLAUSNER, R. D. (1989). Rapid redistribution of Golgi proteins into the endoplasmic reticulum in cells treated with Brefeldin A: evidence for membrane cycling from Golgi to ER. Cell 56, 801-813.

Lodish, H. F., Kong, N., SNider, M. \& STrous, G. J. A. M. (1983). Hepatoma secretory proteins migrate from rough endoplasmic reticulum to Golgi at characteristic rates. Nature, London 304, 80-82.

MizunaGa, T. (1979). Some properties of phosphate-repressible and -constitutive acid phosphatase of baker's yeast. Agricultural and Biological Chemistry 43, 1211-1218.

Munro, S. \& Pelham, H. R. B. (1987). A C-terminal signal prevents secretion of luminal ER proteins. Cell 48, 899-907.

Novick, P. \& SCHEKMAN, R. (1979). Secretion and cell surface growth are blocked in a temperature-sensitive mutant of Saccharomyces cerevisiae. Proceedings of the National Academy of Sciences of the United States of America 76, 1858-1862.

Novick, P., Field, C. \& Schekman, R. (1980). Identification of 23 complementation groups required for post-translational events in the yeast secretory pathway. Cell 21, 205-215.

Novick, P., Ferro, S. \& ScheKman, R. (1981). Order of events in the yeast secretory pathway. Cell 25, 461-469.

ODDS, F. C. \& HIERHOLzER, J. C. (1973) Purification and properties of a glycoprotein acid phosphatase from Candida albicans. Journal of Bacteriology 114, 257-266.

Orci, L., Brown, M. S., Goldstein, J. L., Garcia-Segura, L. M. \& ANDERSON, R. G. W. (1984). Increase in membrane cholesterol: a possible trigger for degradation of $\mathrm{HMG} \mathrm{CoA}$ reductase and crystalloid endoplasmic reticulum in UT-1 cells. Cell 36, 835-845.

PALADE, G. E. (1975). Intracellular aspects of the process of protein synthesis. Science 189, 347-358.

Pelham, H. R. B. (1988). Evidence that luminal ER proteins are sorted from secreted proteins in a post-ER compartment. EMBO Journal 7 , 913-918.

PFefFer, S. R. \& Rothman, J. E. (1987). Biosynthetic protein transport and sorting by the endoplasmic reticulum and Golgi. Annual Review of Biochemistry 56, 829-852.
Ruohola, H., Kabcenell, A. K. \& Ferro-Novick, S. (1988) Reconstitution of protein transport from the endoplasmic reticulum to the Golgi complex in yeast: the acceptor Golgi compartment is defective in the sec23 mutant. Journal of Cell Biology 107, 1465-1476. NiAKR RING

Schekman, R. (1985). Protein localization and membrane traffic in yeast. Annual Review of Cell Biology 1, 115-143.

Schmitt, H. D., Puzicha, M. \& Gallwitz, D. (1988). Study of a temperature-sensitive mutant of the ras-related $Y P T /$ gene product in yeast suggests a role in the regulation of intracellular calcium. Cell $53,635-647$.

Simons, K. \& ViRTA, H. (1987). Perforated MDCK cells support intracellular transport. EMBO Journal 6, 2241-2247.

TAKATSUKI, A. \& TAMURA, G. (1985). Brefeldin A, a specific inhibitor of intracellular translocation of vesicular stomatitis virus $G$ protein: intracellular accumulation of high-mannose type $G$ protein and inhibition of its cell surface expression. Agricultural and Biological Chemistry 49, 899-902.

Tamura, G., Ando, K., Suzuki, S., Takatsuki, A. \& Arima, K. (1968). Antiviral activity of Brefeldin A and Verrucarin A. Journal of Antibiotics 21, 160-161.

TanakA, K. \& Kanbe, T. (1986). Mitosis in the fission yeast Schizosaccharomyces pombe as revealed by freeze-substitution electron microscopy. Journal of Cell Science 80, 253-268.

TARTAKOFF, A. \& Vassalli, P. (1977). Plasma cell immunoglobulin secretion. Arrest is accompanied by alterations in the Golgi complex. Journal of Experimental Medicine 146, 1332-1345.

TARTAKofF, A. \& VASSalli, P. (1978). Comparative studies of intracellular transport of secretory proteins. Journal of Cell Biology 79, 694-707.

WARrEN, G. (1987). Signals and salvage sequences. Nature, London 327, 17-18.

WRIGHT, R., BASSON, M., D'ARI, L. \& RINE, J. (1988). Increased amounts of HMG-CoA reductase induce "Karmellae": a proliferation of stacked membrane pairs surrounding the yeast nucleus. Journal of Cell Biology 107, 101-114. 